\title{
Responsible collaborations Scholarship and cultural heritage assets
}

recently served as a national consultant on collaborations between libraries and museums. ${ }^{1}$ There are not that many articles published about collaborations and cultural heritage collections, although I suspect many unreported activities are being done in the field. From the 2009 program my College Libraries Section (CLS) committee developed when I was CLS chair on town/gown relationships (Our Town, Common Ground) with public and academic librarian panelists to a 2016 article, ${ }^{2}$ cultural heritage institutions and collaboration has been a focus of mine. My life and work experiences gave me a broad exposure to a wide variety of cultures, cultural norms, and an appreciation and valuing of diversity, equity, and inclusion.

The UNESCO's Cairo office's web page describes cultural heritage as the "legacy of physical artefacts [sic] and intangible attributes of a group or society that are inherited from past generations, maintained in the present and bestowed for the benefit of future generations." ${ }^{3}$ Adding to that, Culture in Development posits that cultural heritage is an "expression of the ways of living" created by communities and handed down from one generation to another- "customs, practices, places, objects, artistic expressions and values." ${ }^{4}$ This organization refers to intangible and tangible cultural heritage objects. Tangible objects, part of human activity, refers to representations of "value systems, beliefs, traditions and lifestyles"-i.e., visible culture traceable "from antiquity to the recent past." Intangible cultural heritage is typically voices, values, traditions, and oral history. Today we see this through capture of voice and images (sound and video recordings), but also passed along via religious ceremonies, performances, and storytelling. Tangible heritage is inextricably bound up with the intangible and the delineation is no longer as important as the emphasis and focus on preservation and meaning. Concentration needs to be on the similarities between the various heritage sectors, instead of on their difference in form.

One way to concentrate on the similarities is to use The Heritage Cycle, a concept from the work of Simon Thurley, presented in a diagram that is circular and reiterative. ${ }^{5}$ The Heritage Cycle illustrates that by understanding (cultural heritage) people value it, and what we value we care for, enjoy, and thirst to understand.

Perhaps this is obvious, but current students are not only creating their institutions' cultural heritage collections, but by working with the cultural heritage collections at your institution, these students contribute scholarship to that collection for future students. The activities students engage in during their studies and how they are captured,

Irene M.H. Herold is librarian of the college at the College of Wooster, email: iherold@wooster.edu

() 2019 Irene M.H. Herold 
via newspaper articles, sports, being at a lecture, protesting, and yearbooks, is in text and images for widely differing originally intended audiences. Students are creating cultural heritage that will be studied by generations to come.

Shavonn Matsuda, librarian at the University of Hawai'i at Maui College, stated that "there is an opportunity with cultural collections to represent knowledge in a way that is meaningful to the community. She encouraged us to ask, what is our responsibility to the community whose cultural collections we preserve? We should not be asking what the collection can do for us, but what we can do for the community." I call this "responsible collaborations"-when we understand we are stewards of our cultural heritage holdings. A benefit may certainly be for scholarly research and new knowledge creation, but we must never forget to consider how to be respectful of the originators of the tangible and intangible heritage our collections contain. Just because something is held in our collections does not mean it is available for any use. I urge institutions to move from the concept of collectors and owners to ones of stewards who collaborate and negotiate.

Every institution, every collection, and every item originator has unique aspects that may suggest potential appropriate collaborations. For example, when I asked a question of a new college president about planning for an upcoming college centennial, I found myself asked to be cochair of the pre-event planning. This caused me to think about a splashy way to herald the coming anniversary, without taking too much funding and attention from what would be the main centennial celebration in 2009. A dramatic reenactment in 2007 was the result. ${ }^{7}$ It used the archival collection of college history, historic newspapers, a research of legislation, and became a collaboration with my coauthor and with the theater department for costumes, staging, and direction. Putting the call out to the city council and the college leadership for actors gave the event a spotlight in the celebration of the founding of the college.
While I was not the initiator of a collaboration with Ryukus University, I was the university librarian who approved the partnership and digitization project. The unanticipated result of the importance of access to ancestral scrolls to the Ryukuan people of Okinawa was a prime example of the responsible collaboration as a steward of a collection for the originators, albeit many generations removed. Scholars also benefitted, but it was the reclaiming of history for the people of Okinawa that made our preservation efforts and digitization for access important to the ancestral originators of the collection.

Sometimes it is just sharing that leads to the unexpected. A case in point was with the University of Hawai'i at Manoa Japanese American Veterans 442nd collection. ${ }^{8}$ Visiting high school students from Germany did not expect to see letters in the German language from German War Brides in Hawai'i. It provided a moment for the visitors to think about those experiences, and for their hosts to speak about the melting pot of nationalities the Hawaiian Islands host. It provided a different lens from which to view the World War II experience and cultural isolation.

Incorporation of library materials into courses, while normal for academic and research library collections, with cultural heritage collections provides an opportunity for unique content and perspectives to be considered. An example of this is the use of the Doris "Granny D" Haddock Collection, which served as the basis of a course's oral history project. ${ }^{9}$ The distinctiveness of the holdings extends to the singularity of the educational experience that may be experienced by students in a class that uses exclusive content. It is another way to demonstrate the value and impact of our resources and their relevance to knowledge creation.

Enacting responsible collaborations may be done with tangible and intangible materials of local, national, and international importance. These collaborations provide a way to tell stories of diversity, equity, and inclusion, while responsibly stewarding and preserving knowledge. Academic and 
research libraries have a social responsibility to preserve and present cultural heritage collections for the benefit of the peoples who created and donated the contents, keeping in mind the originator's purpose and intent. It is our privilege to work with them and to creatively share their stories as appropriate.

\section{Notes}

1. This article was adapted in part from a talk given September 28, 2017, at Oberlin College, where I served as a consultant for their Andrew W. Mellon Foundation planning grant, Strengthening Collaborations Between Academic Art Museums and Libraries.

2. Irene Herold, July 2016, "Leveraging Cultural Collections," Library Issues, 36(6).
3. Retrieved October 9, 2017, from http:// www.unesco.org/new/en/cairo/culture /tangible-cultural-heritage/.

4. Retrieved October 9, 2017, from http:// www.cultureindevelopment.nl/cultural _heritage/what_is_cultural_heritage.

5. Simon Thurley, "Into the future, Our strategy for 2005-2010," in Conservation Bulletin [English Heritage], 2005 (49).

6. Herold, "Leveraging Cultural Collections," 2-3.

7. See https://www.keene.edu/news /stories/detail/1345061446198/.

8. See http://library.manoa.hawaii.edu /departments/archives/mss/aja/.

9. See https://commons.keene.edu /handle/20.500.12088/91. n

("Playtime at Robarts Library," continues from page 103)

cally communicate the message that you can be a student and a parent. Welcoming the whole student to the library and the university increases inclusion. Creating family-friendly spaces helps libraries further their mission to provide equitable access to information for their communities.

\section{Notes}

1. Elizabeth Noll, Lindsey Reichlin, Barbara Gault, College Students with Children: National and Regional Profiles (Washington, D.C.: Institute for Women's Policy Research, 2017), 1, https://iwpr.org/wp-content /uploads/2017/02/C451-5.pdf.

2. Canadian Graduate and Professional Student Survey-2016: Summary Report, All Respondents (Canadian Associations for Graduate Students, 2016), 11, www. cags.ca/documents/cgpss/2016/NATIONAL _CGPSS_2016_REPORT_ALL.pdf.

3. Statistics Canada, "Time spent on unpaid care of a child in the household, by working arrangement and age of youngest child, Canada, 2010," table 6 in Women in Canada: A Gender-Based Statistical Report, Statistics Canada Catalogue no. 89-503-X (Jul. 2011), https://www150.statcan.gc.ca /n1/pub/89-503-x/2010001/article/11546/tbl /tbl006-eng.htm.

4. Sonya, "Introducing the RULA Busy Box!," Ryerson University Library and Archives, accessed July 6, 2018, https://library.ryerson.ca/ blog/2018/03/introducing-the-rula-busy-box/.

5. "PGSS Family Collection," McGill Library, accessed July 6, 2018, https://www. mcgill.ca/library/channels/news/pgss-family -collection-230976.

6. "Library Supports and Reference Assistance," University of Alberta, accessed July 6, 2018, https://www.ualberta.ca/augustana /services/aso/programs-and-services/library.

7. "Family Friendly Spaces Campus Guidelines," University of Washington Bothell, accessed July 6, 2018, www.uwb.edu /administration-planning/auxiliary-services /family-friendly-space.

8. "Quick Facts," University of Toronto, accessed July 6, 2018, https://www.utoronto. ca/about-u-of-t/quick-facts.

9. https://www.arlstatistics.org/analytics.

10. University of Toronto, Facts and Figures 2017 (Toronto: University of Toronto, n.d.): 35. https://www.utoronto.ca/sites /default/files/Facts\%20\%26\%20Figures \%202017\%20online\%20version.pdf. „ 